\title{
Relationships Between Risk Tolerance, Financial Sustainability and Economic Resilience in the Context of Industrial Competition
}

\author{
Tatyana Orlova, Aleksandr Timoshin*
}

\author{
Ural State University of Economic, Yekaterinburg, Russia \\ ${ }^{*}$ Corresponding author. Email: sas-timosh@ya.ru
}

\begin{abstract}
The purpose of this paper is to consider the relationships between risk tolerance, financial sustainability and economic resilience. The work also considers the impact of these relationships on the competitiveness of industrial enterprises. The relevance of this study is the fact that at present there is no unanimous opinion on how the interaction of these concepts impacts the development of the economy, including the economy of a business entity. The results of the study may help industrial enterprises to have a better insight into the company's performance; better regulate and control all processes throughout the entire production cycle.
\end{abstract}

Keywords: risks, risk tolerance, financial sustainability, economic resilience, competition, industry

\section{INTRODUCTION}

\subsection{The Concept of Risk Tolerance}

An understanding of risk tolerance has been extensively studied in the Russian academic literature by such authors as Prushchak, Weissman, Zubova, Kail, and Grimashevich. The researchers believe that risk tolerance is linked to efficient risk management that aims at the development and implementation of various risk management measures. According to Prushchak [1], these measures might include:

investments);

ustification of investment goals (risky

- collection of information characterizing various aspects of risk;

- $\quad$ assessment of possible risky situations;

- $\quad$ analysis of risk level;

- justification of an anti-risk program, i.e. a system of measures aimed at reducing risk.

In our opinion, the term 'risk tolerance' can be defined as an ability to regulate internal risks and adapt to the impact of external risks in order to ensure the competitiveness of the enterprise.
Weisman [2] claims that the main criterion for the growth of an enterprise competitiveness is financial sustainability. As it is well known, financial sustainability is a criterion of the business independence and stable financial position, ensured by a sufficient share of equity capital as a financial source [3].

In our opinion, risk tolerance is a broader concept since it includes not only financial sustainability, but also other components that constitute the enterprise economic resilience. Thus, it can be concluded that risk tolerance is an important factor of ensuring sustainable development and viability of the business.

\subsection{The Impact of Risk Tolerance on Economic Resilience}

In the global world, the most important factor for the development of the domestic economy is to ensure economic security of each economic entity, regardless of its size and type of business.

Nowadays, economic resilience is looked upon as one of the most important characteristics of an effective company. The term 'economic resilience' is understood quite broadly and has been discussed in an array of Russian publications. In particular, such authors as Ilyinykh, Suglobov, Khmelev, Orlova, Sharokhina, Ksilinskaya, and Pudovkina consider the importance of 
economic resilience and its relationship with risk tolerance.

Ilyinykh [4] emphasizes the importance of economic resilience in the modern world, since enterprises are facing a variety of external and internal risks, and the competitive economic environment poses numerous threats. Resilience is a meaningful term that describes safety and a low level of risk for a person, society or any other objects or systems. According to the word etymology from Latin and Old French, the term 'safety' means 'free from danger; uninjured, in good health'.

Kasperovich and Derbinskaya [5] argue that the level of the business economic resilience depends on how effectively the management is able to foresee and deal with possible internal and external threats (risks) and eliminate the negative impact of the external and internal environment. The authors also analyze the classification of these threats.

Sharokhina et al. [6] indicate that the enterprise economic resilience is a state of a business entity in which, subject to the effective use of corporate resources, it is possible to prevent or mitigate threats, reduce the negative consequences of unforeseen circumstances and, basically, ensure that the business will be able to achieve its goals in the competitive and risky economic environment.

In general, it can be noted that the enterprise economic resilience is most commonly understood as the state of the most efficient and systematic use of the business resources to prevent various threats and ensure the sustainable development of the company.

At the same time, threats are of key importance in ensuring economic resilience that can be understood as a set of conditions and factors that create a direct or indirect possibility of damaging the enterprise's economic interests [7]. In fact, ensuring economic resilience comes down to meeting these threats.

At the same time, in order to make a right managerial decision while developing business plans, it is important to know the level of the company's economic resilience, i.e. an objective assessment of utilizing the enterprise's resources according to the criteria of economic resilience.

\subsection{Risk Tolerance as Criterion of Measuring Economic Resilience}

There are various methods for measuring risks, and most of them can be successfully applied to the assessment of security risk. The selection of techniques and indicators depends on the current situation, types of presented threats, the volume and reliability of information.
Thus, it is not enough to know what risks the company may face with, it is important to foresee, to identify them in a timely manner. This requires a systematic analysis of the key performance indicators of the enterprise, and the design of an innovative strategy for business growth.

Kocherygina and Panikarov [8] believe that it is possible to successfully identify potential risks by analyzing (auditing) the company's financial statements. They argue that the analysis of the balance sheet in terms of the magnitude of risks might significantly simplify the risk manager's job, since it might allow the manager to focus on the most important aspects of the enterprise performance and to identify the areas of risk elimination. Using the balance sheet risk analysis contributes to improving the stability of the enterprise in the unstable market environment. The analysis of the financial structure and effective financial management may ensure the financial sustainability of the company in a timely manner.

The purpose of the paper is to offer a theoretical understanding of such concepts as risk tolerance and company's economic sustainability and to establish the relationship between these concepts.

\section{METHODOLOGY}

In modern conditions of fierce competition, ensuring the economic sustainability of the state and individual economic entities has become more relevant than ever. The solution of this problem is essential for ensuring the sustainable growth of national economies that are based on effective performance of economic entities.

Changes in the social system have dramatically affected the previously established market relations. The unpredictable variability of the external environment has led to increased uncertainties between business entities. As a consequence, the impact of both external and internal risks on the company's performance has enhanced.

Systematic control of risks, their regulation and coordination are necessary, and timely management actions to reduce risks will certainly contribute to improving the enterprise's economic sustainability. Thus, the relevance of risk studies to business performance is the key factor in business development and provision of economic stability in the market [9].

The most general classification of techniques allowing to assess business risks, divides them into two large groups: quantitative methods and qualitative methods. Industrial enterprises prefer applying quantitative methods of risk assessment, such as volatility analysis, grouping method; analytical methods such as scenario method, decision tree method, simulation modeling. The choice of these methods is 
explained by a large amount of data that is increasingly being converted to a digital format. However, the use of quantitative risk assessment methods might be impractical without a preliminary qualitative analysis (the Delphi approach).

In order to manage the competitiveness of an industrial enterprise, certain actions are required, the actions that will allow the enterprise to improve, monitor and forecast the work of all departments. The main goal is to develop a mechanism to enhance business competitiveness, which implies three main stages: Stage 1 - Research and Data Collection; Stage 2 - Result Processing; Stage 3 - Recommendations. For each of the stages, various techniques should be applied: external and internal environment analysis for Stage 1; the SWOT analysis, the PEST analysis, and risk analysis for Stage 2; the application of the necessary measures to achieve the result for Stage 3 .

In the strategy of small and medium-sized enterprises (SMEs) approved by the Decree of the RF Government, dated March 02, 2016, the key indicators of development are a larger share of small businesses in the industrial sector; growth of SMEs; the introduction of innovations and the development of export-oriented industrial and manufacturing enterprises. The necessary condition for promoting the development of these SMEs will be their risk tolerance [10].

The financial stability of an enterprise is made up of many indicators, that is why it is important for managers to identify the key ones in the present conditions in order to objectively assess them.

It is worth noting that so far not all types of risks of industrial enterprises in terms of economic sustainability have been considered, in particular, the risks industrial enterprises are facing in the era of digitalization.

By making an attempt to analyze risks of industrial enterprises, Latypova and Kiselevich [11] present only the general classification of risks, their sources, factors and ways of reducing risks. More detailed views on risk components are discussed in the works of Fadeeva, Rodina, Flegontov, and Lankina. These authors focus on classifications and the issue of risk assessment of an industrial enterprise. However, a more comprehensive study of risks is needed, in terms of maintaining economic sustainability under the conditions of digitalization of production processes. There is also a need in creating a dependency model with various indicators of an industrial enterprise's financial performance.

The specifics of the risks of industrial enterprises are in compliance with the requirements of state standards of the state-commissioned manufactured products.

Ramenskaya [12] analyzed interrelation between risk and revenues using the case of companies involved in steel, wood processing, chemical and oil industries. She has come to the conclusion that there is a negative relationship between risk and profit indicators for the majority of the companies in the sample. These findings are confirmed in the works of Bocharov, Aleksentseva, Ermoshin, Rodina, Fadeeva, Lankina, and Flegontov.

It should also be noted that the digital economy provides more opportunities for a deeper operational and qualitative assessment and decision-making on risk management. Nowadays the control of production processes and the analysis of financial indicators are increasingly carried out with the application of digital tools. Therefore, it is essential to strictly comply with the requirements for economic sustainability assurance and risk tolerance monitoring. Many risks of industrial enterprises, especially risks related to financial reporting, can have a strong impact on the company's financial performance and its sustainable development.

\section{RESULTS AND DISCUSSION}

Nowadays digitalization has become a popular topic for discussion not only in the academic environment, but also in the business community, government circles and society as a whole. The popularity of this issue is explained by a significant contribution that digitalization makes to the economic and social development. It serves as the technological basis for the transformation of economic activity following the 'knowledge intensive' scenario, which contributes to the implementation of the strategy of social and economic breakthrough.

Accelerated digital development has a significant impact on business and the industrial sector in particular. This impact is multifaceted and deserves a comprehensive study and/or an independent research program. Since it is impossible to cover all aspects related to this topic in one article, the aim of the present paper is to study a question; How to ensure economic sustainability of an industrial enterprise, taking into account such a new factor as digitalization?

In Kolomytseva's opinion [13], digitalization can impact as follows:

- Physical threats are still important and the company can neutralized them by using traditional methods, e.g., by 'authorized staff only' access and business operating practices. Digitalization has not changed the nature of physical threats;

- Information threats are obviously undergoing the most significant changes in the context of digitalization. Indeed, cybercrime is becoming one of the most dangerous and difficult to detect social phenomena;

- The link between economic and legal threats. In this case the impact of digitalization is similar to the impact on physical threats. 
Boundaries between certain types of threats are blurring, as the threats are becoming digitalized, which is determined by the penetration of digital technologies into all business and management processes of the enterprise. Digitalization makes the information about the company more transparent, hence it increases the company's vulnerability to damaging influence. At the present time, the business itself is also becoming more digital. Thus, rapid digitalization of the socio-economic system that we witness today causes significant changes in ensuring the economic sustainability of enterprises.

These changes are not sufficiently studied and require theoretical understanding. Nevertheless, it is possible to identify some specific features that determine the degree of ensuring the economic sustainability of enterprises in the digital economy. A high level of the business financial stability along with its competitive advantages and digitalization of business processes will enable timely tracking of risk tolerance.

The enterprise can gain and maintain the required level of competitiveness with effective management only. Management of competitiveness could be understood as a purposeful process of coordinated effects on management objects in order to gain, ensure and maintain the necessary level of competitiveness of the enterprise in the market.

Some authors [14] discussed the risks of digitalization of industrial companies. They reported the general trends in the company's perception of digitalization risks and gave an overview and development prospects for neutralizing risks, including operational and information stability risks. It can be concluded that a more detailed and in-depth study of the risks of industrial enterprises in the digital economy is needed.

Vasin [25] presents types of digital technologies used at enterprises; Big Data, cloud technologies, neural network technologies, artificial intelligence, auxiliary and 3D-manufacturing technologies, cyber-physical systems (CPS), Internet of things, robotics, sensors, quantum sensors, industrial analytics, mathematical modeling and forecasting, etc.

According to Shcheglov [16], the key avenues of the digital economy are the development of robotics, artificial intelligence, 3D-printing, mobile devices, data storage and processing technologies, etc. Modern environmental conditions are extremely variable; as a result, the relevance of the enterprise sustainable development and the determination of its features increase in the current situation.

Thus, the relevance of research in these areas is a key factor in the development of business entities and assurance of their economic sustainability in the market.
For large manufacturing enterprises with a clearly standardized product, competitiveness is primarily determined by the ability to retain and expand the market share. The manager's most important priorities are cost reduction and higher turnover of working capital.

Another issue is the territorial division of labor. It involves the spatial placement of various types of jobs, which is affected by climate, access to resources, infrastructure development, regional economic policy (including international markets). However, with an increase in innovative products and production, with the growth of globalization and digitalization, the effect of this factor on production differentiation is significantly dampened [17].

The analysis of the industrial sector in the Urals Region for the past 10 years shows a certain degree of stagnation due to sanctions from foreign countries, and the need for modernization of the production processes. Therefore, the use of digital technologies can have a positive impact on the development of the industrial sector as a whole [18].

Inefficient economic, institutional, and financial mechanisms do not allow SMEs to interact effectively at the interregional level. Meanwhile, in order to respond to big challenges, Russia should establish stable, effective interregional networks rather than staying a regionally divided country [19].

At the moment industrial companies need to be transformed in order to expand their positions in the market. The introduction of digital technologies is vital. It is essential to enhance corporate goodwill; constantly monitor the need for production technologies upgrade; control the quality of manufacturing process; monitoring the staff performance and professional development. Krylatkov and Baranchikova [20] think that the key factor of the industrial enterprise performance is the control over the production process. The way products are manufactured will affect the future position of the enterprise in the economy. These conditions can be satisfied with the help of digital technologies. It is important to decide what, how and where should be introduced in the production process. Further research might identify promising directions for improving the activities of industrial enterprises with the help of digital technologies.

\section{CONCLUSION}

To sum up. Under the modern conditions of economic instability and growing competition, there is a high degree of uncertainty in both the external and internal environment. In this regard, timely identification of potential risks and assessment of their impact on the efficiency of the enterprise are relevant for every business entity. 
No doubt, the problem is complex and multidimensional. In this regard, there is an objective need to continue to study different aspects of risk management. The authors made an attempt to analyze and systematize the approaches offered by Russian researchers to such concepts as risk tolerance, economic sustainability and competitiveness. Financial sustainability was discussed as an importance factor of the business entity performance, since it will allow timely tracking of the overall level of risk tolerance in the company.

Using the statistical data of the industrial sector in Sverdlovskaya Oblast, the case of a specific enterprise was presented and the relationships between financial sustainability and economic stability of the enterprise were substantiated using the calculation of a number of financial coefficients characterizing liquidity and financial stability. The application of this approach is aimed at timely identification of potential risks, as their management will contribute to company's better competitiveness in unstable (uncertain) market relations.

Digitalization of the economy forces the enterprise to solve a twofold task. On the one hand, the impact of the current situation has led to the emergence of new risks. On the other hand, the development of technologies and the emergence of new methods of information analysis and reporting contribute to practical application of risk theories and an offer of new opportunities for risk identification and assessment. This, in turn, might result in improving the indicators of risk tolerance, economic sustainability and competitiveness.

\section{REFERENCES}

[1] O. V. Prushchak, Risk management of sustainable development of innovative enterprises, In: Bulletin of the Saratov State Social and Economic University, 2

(2014). https://cyberleninka.ru/article/n/upravlenie-riskomkak-faktor-ustoychivogo-razvitiya-innovatsionnyhpredpriyatiy.

[2] E.D. Vaisman, Financial stability as a criterion for the competitiveness of an enterprise, In: Finance and Credit, 45(381) (2009). https:/cyberleninka.ru/article/n/finansovayaustoychivost-kak-kriteriy-konkurentosposobnostipredpriyatiya.

[3] Financial stability of the enterprise: assessment and decision-making, In: Information portal Business and service. https://dis.ru/library/551/22441/.

[4] A.S. Ilyinykh, Economic security of the enterprise, In: International journal of the humanities and natural sciences, 1 (2016). https://cyberleninka.ru/article/n/ekonomicheskaya- bezopasnost-predpriyatiya-3.

[5] S.A. Kasperovich, E.A. Derbinskaya, Economic security of the enterprise: essence, goals and directions of provision, In: Proceedings of BSTU. Series 5: Economics and Management, 7(189) (2016).

https://cyberleninka.ru/article/n/ekonomicheskayabezopasnost-predpriyatiya-suschnost-tseli-inapravleniya-obespecheniya

[6] S.V. Sharokhina, M.V. Kislinskaya, O.E. Pudovkina, Economic security of enterprises as a factor in ensuring economic stability, In: Bulletin of Eurasian Science, 5(42) (2017). https://cyberleninka.ru/article/n/ekonomicheskayabezopasnost-predpriyatiy-kak-faktorobespecheniya-ekonomicheskoy-stabilnosti

[7] Decree of the President of the Russian Federation. Strategy of economic security of the Russian Federation for the period up to 2030. 208 (2017).

[8] E.E. Kocherygina, V.A. Ponikarov, Organization of industrial enterprise management based on risk assessment, In: Russian Journal of Entrepreneurship, 15(2) (2014) pp. 121-131. https://cyberleninka.ru/article/n/organizatsiyaupravleniya-promyshlennym-predpriyatiem-naosnove-otsenki-urovnya-riskov.

[9] T.S. Orlova, A.A. Timoshin, G.A. Yarin, Financial planning of risks of small enterprises, In: News of higher educational institutions. Ural region, 2 (2018) pp.

17-25. https://www.elibrary.ru/item.asp?id=35344693

[10] [Official portal Yekaterinburg.rf. Industry and entrepreneurship of Yekaterinburg. https:екатеринбург.рф/дляработы/промышленно сть-предпринимательство

[11] R.R. Latypova, A.G. Kiselevich, Analysis of industrial enterprise risks, In: Service theory and practice: economics, social sphere, technologies. 2(24)

https://cyberleninka.ru/article/n/analiz-riskovpromyshlennogo-predpriyatiya

[12] L.A. Ramenskaya, On the paradox of profitability and risk in Russian industrial companies, In: Manager, 56(4) (2015) pp. 36 http://upravlenets.usue.ru/ru/-2015/270

[13] O.Yu. Kolomytseva, V.A. Plotnikov, Specificity of ensuring the economic sustainability of enterprises in the context of digitalization of the economy, In: Izvestia SPbGEU, 5-1(119) (2019). https://cyberleninka.ru/article/n/spetsifikaobespecheniya-ekonomicheskoy-bezopasnosti- 
predpriyatiy-v-usloviyah-tsifrovizatsii-ekonomiki

[14] V.V. Borisova, O.V. Demkina, A.V. Savin, Risks of digitalization of industrial companies, In: Innovations and investments, 12 (2019). https://cyberleninka.ru/article/n/riski-tsifrovizatsiipromyshlennyh-kompaniy

[15] N.S. Vasin, Enterprise sustainability management in the digital economy, In: Economic analysis: theory and practice, 17(6) (2018) pp. 1100 - 1113.

[16] E. V. Shcheglov, Features of sustainable development of industrial enterprises in the digital economy, In: Gaudeamus Igitur, 4 (2018) pp. 11-15.

[17] N.Yu. Yaroshevich, Research of industrial differentiation in industrial markets of mechanical engineering: supply factors, In: Manager. -. - T. 11, 5 (2020) pp. 47-57. http://upravlenets.usue.ru/ru/$2020 / 694$.

[18] A.A. Maltsev, Ural industry: opportunities for growth in the post-crisis phase, In: Manager, 53(1) (2015) pp. 22. http://upravlenets.usue.ru/ru/2015/231-2015-03-11-07-24-13.

[19] V.I. Barkhatov, D.S. Benz, Industrial markets of the Ural region: economic growth in the context of the "new normality", In: Manager, 10(3) (2019) pp. 83-93. DOI: 10.29141/2218-5003-2019-10-3-8.

[20] P. P. Krylatkov, S. G. Baranchikova, Stakeholder management in the creation of consumer value for the products of an industrial enterprise, In: Manager, 9(5) (2018) pp. 58-64. http://upravlenets.usue.ru/ru/-2018/516. 